\title{
THE STORYTELLING: AN EFFECTIVE TOOL IN THE TEACHING OF HIGH-LEVEL CHEMISTRY
}

\author{
Elena Vasilevskaya, Natalia Boboriko \\ Belarusian State University, Republic of Belarus
}

\begin{abstract}
"There are two things that science needs to do:
The first is we need to talk about why, and the second is that we need to tell a story."

Atif Kukaswasdia, TEDx speaker
\end{abstract}

\begin{abstract}
Storytelling is a teaching method that presents learning material through personally significant stories and associates with the personal experience of the teacher and student. This method trains the ability to work with information, teaches to analyze situations and evaluate alternatives, correlates the studied theoretical material with practice, develops the skill of solving practical problems.

Types of pedagogical storytelling and building of the story were reviewed. Using storytelling in higher chemical education is discussed. It is shown that literature and science literature, publications in the media, art, history of chemistry, current stage of the scientific research, and real production experience can be used as information sources for creating educational stories in chemical education. Examples of the use of storytelling in the preparation of students at the Faculty of Chemistry of the Belarusian State University are given.
\end{abstract}

Keywords: storytelling, chemistry education, history of chemistry, chemistry laboratory practice

\section{Introduction}

The formation of key competencies of the 21 st century and the training of new generations of students require a significant revision of the traditional education system, which is focused on the reproduction of knowledge. Narrative pedagogy is an interpretive approach to teaching and learning that evolves from the lived experiences of teachers and students. One of the teaching methods in this case is storytelling. Storytelling in education is based on the narration of the stories, which are not only related to the studying subject but also are associated with the personal experience of the narrator and listener (Chelnokova, 2017; Gallagher, 2011; Green, 2004; Kortam, 2020; Landrum, 2019; Storr, 2019). At the same time, both the problem of transferring educational information and the problem of increasing the motivation of students, the development of their communicative competencies are solved.

It should be emphasized that this method is not fundamentally new, since the presentation of material through personally significant stories has traditionally been present in the learning process. But at the present stage, the application of the storytelling method implies a kind of repackaging of information content, i.e., giving a new structure and form to the known content. At the same time, forms of information transfer that are in demand by the modern generation of schoolchildren and students can be implemented: instead of questions and answers in the traditional form - chatting; instead of a long text - a checklist, instead of a list of events - a timeline of all episodes. 


\section{Pedagogical Storytelling}

The use of storytelling in teaching is based on the peculiarities of human psychological perception: stories turn to be more enticing, interesting, emphatic, and easy to relate to personal experience in comparison with rules and strict directives. Consciousness makes stories more memorable and more influential on people's behavior. During the teaching process stories are aimed to arouse cognitive interest, create favorable conditions for memorizing the past material, give information a familiar and accessible form, and to make the teacher - student relationship more personal (Green, 2004).

There are two main types of pedagogical storytelling described in the literature: classical and active (Chelnokova, 2017; Ermolaeva, 2016, 2017). Implementation of classical storytelling means that the teacher verbally or in the form of a text conveys information to students, which is based on a real-life situation or an invented story. In the story, explicit knowledge is broadcasted to students: specific educational information, rules, theories, experimental laws, clothed in the form of a memorable story.

When the active storytelling (case story) is implemented, the teacher sets the basis for the story, and students are actively involved in the process of creating and telling it. At the same time, students can not only analyze stories, simulate various situations and look for ways out, but also create stories on their own, following the instructions and recommendations of the teacher. It should be noted that active storytelling contributes to the transmission of not only explicit but also implicit knowledge, which is not logically formalized and verbally expressed (Ermolaeva, 2017). Implicit knowledge especially manifests itself in practical activity and represents the transfer of skills and abilities.

\section{Building the Story}

Using storytelling in science education means creating a narrative. Maria Homann (2017) suggested that the case story should contain the following elements:

a) a detailed description of the location of the story and its timing;

b) the main characters of the story, which should be topical, interesting and namable;

c) the plot of the story, which is carefully structured and correlated with the events' sequence;

d) the problem or dilemma that creates emotional involvement of the reader or listener;

e) humor, fun and/or gamification elements that improve the perception of the story;

f) beacons that link the story to real-life experience;

g) "cliffhanger", that leaves the students in a problem-solving state of mind.

It is important that the story contains information already known to the audience, which is gradually supplemented with new information. In this case, it is necessary to adhere to a certain structure of the story (figure):

- the introduction raises a question, denoting a conflict or a problem that needs to be solved, explains its relevance to the audience;

- development of events, aggravation of the problem;

- a culmination, problem resolution. We get the answer to the question, and this answer, most often, is not at all what was expected;

- a conclusion that sums up the story in one sentence. 


\section{Figure}

The Narrative Outline

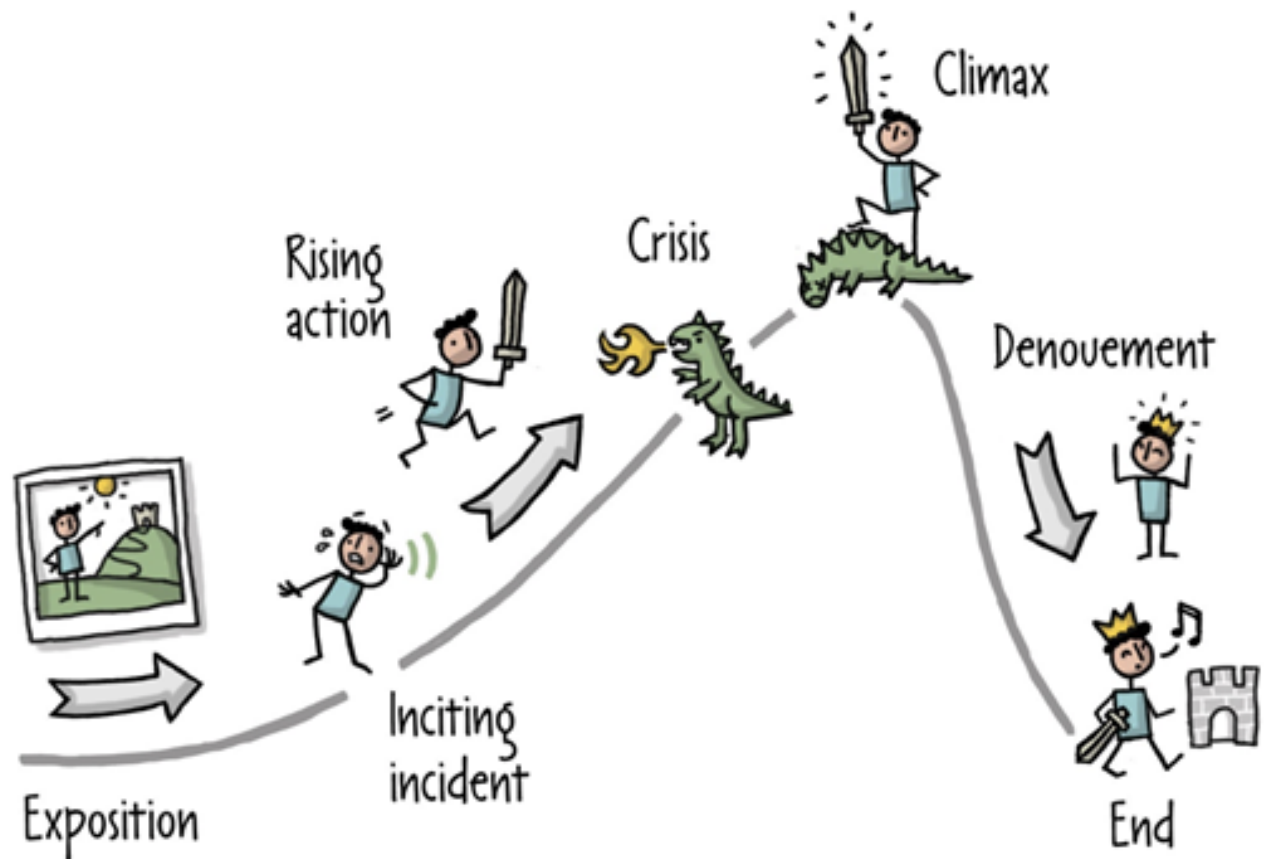

Source: www.miro.medium.com

An important point is getting feedback from the audience. It is worth finding out what was most memorable, whether interest in the story remained throughout the entire narrative.

\section{Sources of Information for Storytelling and the Examples of Their Use in the Study of Chemistry in University}

The method of storytelling is traditionally used during all stages of continuous chemical education (Bolte, 2013; Collins, 2021; Dias, 2021; Ihde, 1971; Folino, 2001; Milanovic, 2020; Morais, 2015; Pabuccu, 2016; Peleg, 2017; Winston, 2017). Its use in the early stages of education is widely known, while storytelling in university education is not used as often as possible.

When using the storytelling method, an important issue is the choice of information sources for creating educational stories. In particular, when studying the disciplines of the chemical cycle, such sources can be fiction, journalistic and scientific literature, industrial experience, etc. Let us consider these sources and examples of their use in more detail.

\section{Literature and Art}

The use of literature in teaching chemistry is most often used in secondary school. For example, detective stories can be used (Dias, 2021), including those based on individual 
plots in the novels of A. Conan Doyle or A. Christie, who, by the way, was a pharmacist by education. For university students, storytelling based on fantastic works is of greater interest (Stocker, 1999).

The use of stories of art objects is also noteworthy. For example, when studying the chemistry of cobalt in the Inorganic Chemistry course, the use of cobalt pigments in painting can be discussed with the attention to one of the most famous paintings by Van Gogh "Starry Night", for which he used thenar (cobalt) blue. Material for preparing such a story can be found in the article (Chalecki, 2012). At the same time, students can be invited to familiarize themselves with the first publication on the synthesis of thenar (cobalt) blue that was published in the French mining journal (Thénard, J., 1803-1804). Talking about the history of cobalt pigments in painting, one can move on to the modern application of these compounds in innovative technologies. So, it turned out that cobalt (or Riemannian) green has unique magnetic properties that make it possible to use it in spintronics, a field of physics that studies the transfer of electric current using the electron spin in solids (Green pigment, 2006).

\section{Science Literature, Publications in the Media}

Many ideas for storytelling can be found in the popular science literature on chemistry (Aldersey-Williams, 2011; Asimov, 1962, 1974; Ball, 1994; Buchachenko, 2020; Farmer, 2017; Hoffman, 1997; Jaffe, 2012; Kean, 2011; Kuramshin, 2017; Le Couteur, 2003).

Fragments of articles and materials from the media significantly actualize the story being told, increase students' interest in it. So, for example, when studying the topic "Solutions" in the course of Inorganic chemistry, students of the Faculty of Chemistry of the Belarusian State University (BSU) are invited to analyze the texts posted in the media, find chemical incorrectness and fake news in them and (if desired) offer their own version of the text. Most often these are texts about water, the content of various impurities in it, the value of the hydrogen index $(\mathrm{pH})$ in various aqueous media. The creation of such stories contributes not only to the formation of chemical literacy but also to the development of critical thinking among students, which is very important in the modern world (Locatelli, 2021).

\section{History of Chemistry, the Role of Private Persons}

Materials related to the history of the development of chemistry as a science, the role of individuals and the fate of their discoveries always attract attention. The use of the historical approach in teaching chemistry has been studied for many years (Hargittai, 2002, 2003; Jaffe, 2012; Kortman, 2020; Kuramshin, 2017; Machanti, 2014; Milanovic, 2020; Rayner-Canman, 1998;). In order to form students' knowledge of the conceptual aspects and processes of science a convenient pedagogical approach can be used that implies integrating of short historical stories in chemistry teaching. In this approach teachers can acquaint the students with the chronology of scientific discoveries and time evolution of scientific ideas. At the same time, it is important to talk about the work of national scientists. For example, in "Some Pioneers of Modern Chemistry", the 35 biographical sketches deal chronologically with the lives and the contribution to chemistry by world-class chemists. The author (Machanti, 2014) talks about both international and Indian scientists such as the founder of the Indian school of modern chemistry Acharya Prafulla Chandra Ray (18611944). 
Chemistry interest increases when students learn about the specific applied research problems that could not be solved without a thorough knowledge of chemistry, especially if these problems were resolved with the help of the scientist that worked earlier in the same institutions as the students. In the Chemistry Faculty of the Belarusian State University, the students are proposed to discuss some of the scientific achievements of Boris Berkengheim, the first Head of the Inorganic Chemistry Department of BSU in 19211927. Boris Berkengheim graduated from Moscow University where he was engaged in scientific research under the guidance of Nikolai Zelinsky, a famous organic chemist. The text of the task is given below.

"During the First World War, after the start of the use of chemical weapons, Boris Berkengheim together with his teacher Nikolai Zelinsky was engaged in the development of the fillers for filter cartridges for gas masks with the ability to absorb a wide range of chemical warfare agents. The result of this work was the development in 1915 of the Zelinsky-Kummant gas mask, a prototype of modern gas masks adopted during the First World War by the Russian army and in the allied armies. Development of new fillers for filter cartridges for gas masks got off on the basis of a composition of the already existing German cartridges, which were a tin box filled with diatomite or pumice grains, 2-3 mm in diameter, impregnated with a solution of sodium hyposulfite and potash and covered with a thin layer of charcoal. By July 1915 at the Mining Institute in Saint-Petersburg, soda-lime granules were tested as an absorbent. The gas mask of the Mining Institute protected the soldiers from chlorine, hydrocyanic acid, bromine. However, the gas mask had a significant drawback when the pellets came into contact with the soldier's exhaled air, which led to his withdrawal from the active army in 1916. The main difference between the filter cartridge of the Zelinsky-Kummant gas mask was its filling with activated carbon without the use of any other chemical absorbers of toxic substances.

1. Explain the purpose of each of the components of the German cartridge, taking into account that the German troops utilized mainly chlorine at the beginning of the use of chemical weapons. Write down the necessary equations of chemical reactions.

2. Write down the chemical formulas of all substances of the German cartridge, taking into consideration that the main component of diatomite and pumice is oxide, the ratio of the mass fractions of the components in which is 1.139 .

3. Write down the reaction equations reflecting the processes of chemical absorption of toxic substances by the soda-lime filler.

4. What drawback prevented the effective use of the gas mask of the Mining Institute in combat conditions?

5. Give a general scheme of the obtaining of activated carbon from wood.

6. What chemical and physical processes make the use of activated carbon in gas masks successful?"

Answering the questions of this task students should analyze the applications of all the mentioned in the task chemical compounds and choose those of them which are adequate for use in the filter cartridges. During this step, students have to think over both physical and chemical properties of the compounds to distinguish the purpose of each component: diatomite or pumice grains were used in the cartridges as a carrier of the active compounds, sodium hyposulfite aimed reduction of the chlorine gas, potash was used for chemical binding of the exhaled carbon dioxide and to neutralize hydrochloric acid that can be formed during the reduction of gaseous chlorine, and charcoal was used for physical adsorption of the hazardous substances. Chemical formulas of some of the 
mentioned substances are well known for the students (potash $\mathrm{K}_{2} \mathrm{CO}_{3}$, charcoal $\mathrm{C}$, sodium hyposulfite $\mathrm{Na}_{2} \mathrm{~S}_{2} \mathrm{O}_{3}$, soda-lime $\mathrm{NaOH}$ and $\mathrm{Ca}(\mathrm{OH})_{2}$ mixture), while diatomite or pumice as chemical compounds are less widespread in student practice. In order to give students a chance to obtain the right answer even if they do not know the chemical formula of diatomite or pumice, mass fractions of the components in this oxide are given in the task. With its help, students can calculate the atomic mass of the second element in the oxide and establish the chemical formula of the oxide $-\mathrm{SiO}_{2}$, which is the main component of both diatomite and pumice. If students are allowed to use literature sources during the work on this task, the difference in the chemical composition of diatomite and pumice can be discussed. The main chemical part of the task lies in the analysis of all the possible chemical reactions between the hazardous substances and the chemical components of the filters. Students should quote the chemical reactions of the interaction of chlorine gas with sodium hyposulfite, chlorine gas with sodium hydroxide, bromine with sodium hydroxide, potassium carbonate with hydrochloric acid, sodium hydroxide with hydrocyanic acid.

The interesting part of the task is the analysis of the possible drawbacks that prevented the effective use of the gas mask on the basis of soda-lime in combat conditions. Two main drawbacks can be discussed. During the use of the mask, $\mathrm{CO}_{2}$ is exhausted. In soda-lime filters $\mathrm{CO}_{2}$ can be chemically absorbed both by $\mathrm{NaOH}$ and $\mathrm{Ca}(\mathrm{OH})_{2}$. The products of these reactions are sodium or calcium carbonate respectively and water. Water also is a component of the exhausted air. A large amount of water can cause two main problems in the intense use of soda-lime filters. Firstly, $\mathrm{NaOH}$ and $\mathrm{Ca}(\mathrm{OH})_{2}$ can deliquesce in water and block the filter box restricting breathing in the mask. Secondly, $\mathrm{NaOH}$ can form a fog with water vapors irritating breathing passages and blocking breathing.

The use of activated charcoal allows getting around these difficulties. The efficacy of the activated charcoal consists in its very high absorbability and the possibility of the additional reduction or oxidation of the adsorbed hazardous substances by the surface functional groups. During the work on this point students have to examine in detail the following questions:

- the process of obtaining of the activated charcoal;

- the meaning of activation of the coal (opening of the pores) that makes the difference between the activated charcoal and charcoal;

- the main physical and chemical characteristics of the activated charcoal, which make it highly useful in the filters.

This task emphasizes the role of chemistry in real practical applications in the creation of the equipment to protect people and to rescue human lives. As a continuation of this task students can prepare the projects on the use of activated charcoal as medicine and in water filtration.

\section{Development of Chemical Concepts and Ideas}

In chemistry, many things can be interpreted ambiguously, for example, the theory of chemical bonding can be considered from the point of view of both the method of valence bonds and the method of molecular orbitals. In the study of chemical disciplines, one can consider the chemical and physicochemical processes occurring during the synthesis, use, and storage of substances and materials. It is important to show how chemical concepts are changing, how much work is behind each science information in the textbook. Moreover, the situation under consideration can reflect both a complex problem in accordance with the studying topic and a real-life story. 


\section{The Current Stage of the Scientific Research}

In the practice of higher education, stories based on work with the texts of original scientific articles, monographs, reports, including those in foreign languages, are of great importance. The main task of the teacher in this case is to transform the results of scientific research into a fascinating story (Luna, 2013). The meaning of the history of the research lies in the fact that it acts as the basis for obtaining new knowledge and for acquiring the skills of scientific research. If the works of journalism and fiction give emotional richness and tangibility to history, then scientific materials give it greater rigor and correctness.

An interesting example for use storytelling is in the article (Lopesa, 2020). The scientists of multinational scientific research group in the field of bioinorganic chemistry tell seven short stories about their experiments. Taking into account that their scientific group collaborates scientists from five different countries of South America, Europe, and Australia, the stories told illustrate the significance of science for the society, underline multicultural aspects of science, and illustrate the importance of fundamental research for the development of science and its practical applications.

A good scientific article is usually characterized by an in-depth understanding of a subject. Using storytelling in chemistry teaching can be based on the truthful facts and stories about specific scientists and their gaining the knowledge and information, which is studied by students. For example, when studying the special discipline "Surface Chemistry", students of the Faculty of Chemistry of the BSU, on the basis of a publication in a scientific journal or information found on the Internet, prepare a story about the use of natural objects in the creation of chemical sensors. At the same time, scientific publications and their fragments can act not only as components of history but can also be included in the list of literature necessary for its understanding.

Tasks of this type promote cognitive interest in science among students, develop problem-solving abilities of the students, and show the hard work of the scientists in obtaining knowledge and formulation of scientific ideas.

\section{Real Production Experience}

The storytelling method in chemistry education is often based on stories from real production experience and the activities of specialized companies. Stories from the world of business provide an opportunity for students to get acquainted with the problems that are facing real chemical companies. In this case, students can try to apply their theoretical knowledge to solve the described problem. The teacher, as a rule, is well aware of the specifics of the work of a particular enterprise, especially if the department maintains contacts with its specialists and prepares graduates for work in this direction.

At the same time, there is a unique opportunity to invite the head of the enterprise or a leading specialist to talk about solving a profile chemical problem. The use of such stories increases the motivation of students, stimulates them to acquire the knowledge, which is necessary for their future professional activities.

\section{Storytelling during Chemistry Laboratory Practice}

During laboratory classes in Inorganic chemistry at the Faculty of Chemistry of the Belarusian State University, active storytelling techniques were tested, aimed at the 
consolidation of the knowledge in safety engineering in a chemical laboratory. For this, the "real life" situations described in the manual (Zakharov, 1991) were reworked: working with chemical vessels, preparation of a sulfochromic mixture, handling with alkali metals, etc.

The following case story can be an example. In the case story "Sulfochromic mixture" the task was to repeat the safety rules when working with caustic and hazardous chemicals, to consolidate knowledge about the handling with sulfochromic mixtures when working in a chemical laboratory. At the first stage of the work, students were provided with a text for familiarization, which considered the rules for the preparation of a sulfochromic mixture and working with it.

Then, at the incident stage, the following situation was considered: "During the preholiday cleaning of the laboratory, senior researcher A. ordered the laboratory assistant to combine the sulfochromic mixture that was in the fume hood in two thick-walled glass jars. Both jars with a capacity of $2 \mathrm{dm}^{3}$ each contained approximately $1 \mathrm{dm}^{3}$ of sulfochromic mixture and both had labels with the inscription "Sulfochromic mixture". A few seconds after draining, the contents of the jar boiled violently and poured out. Lumps of cotton wool and filter paper lying nearby that were used earlier to wipe closing glass of the ventilation hood ignited immediately when the mixture got on them. Fortunately, there were no other combustible materials in the fume hood and the ignition was eliminated with a carbon dioxide fire-extinguisher" (Zakharov, 1991).

At the next stage of working with the case story, students were asked the following questions and tasks for discussion:

1. Why do you think this situation happened?

2. What types of sludge can be cleaned with the sulfochomic mixture?

3. Why sulfochromic mixture can be dangerous for human health? What main precautionary measures should be observed during the work with the sulfochromic mixture?

4. What chemical reactions characterize the chemical properties of concentrated sulfuric acid and concentrated nitric acid? Write the appropriate chemical equations.

5. Do you think it is possible to use diluted acid solutions to prepare the sulfochomic mixture? Why?

6. What oxide is formed during the interaction of the acid and potassium dichromate (write the reaction equation)?

Based on students' assumptions, a case story solution should be formulated: "Analysis of the incident allows concluding that one of the jars contained a previously prepared sulfochromic mixture on the basis of concentrated sulfuric acid, and the other jar contained a fresh sulfochchromic mixture from concentrated nitric acid and potassium dichromate. Sulfochromic mixtures based on nitric acid have never been used in the laboratory before. Researcher B., who prepared the second mixture, did not change the old label on the jar. At the time of the incident, he was not in the room. The given example shows that the cause of the incident was not a direct violation of any safety rules, but only insufficient discretion by both researchers. Researcher B., who prepared the chromium mixture according to a new recipe, should inform anyone about it" (Zakharov, 1991).

In this case, we are dealing with practice-oriented storytelling, when the recounted story in detail reflects the real situation from laboratory practice. The educational purpose of such a story aims to train students, consolidating knowledge, skills and behavior, and decision-making in a given situation. Thus, attention is focused on compliance with the 
rules of safe behavior when working in a chemical laboratory. At the same time, during the discussion of the story, students' communication skills are developed, abilities are formed that allow them to interact and make collective decisions, to find the necessary knowledge to solve problems arising in professional activities.

\section{Conclusions and Implications}

It should be noted that within the framework of the storytelling method, a significant part of the educational material on chemistry can be considered since this method trains the ability to work with information, teaches to analyze situations and evaluate alternatives, find and choose the most rational solution, draw up a plan for its implementation, correlates the studied theoretical material with practice, develops the skill of solving practical problems. Storytelling gives students a deeper understanding of science and allows implementing an interdisciplinary approach in teaching.

Stories guarantee emotional engagement of the students. This emotional involvement aids in content retention, with obvious benefits to grades, class rank, and job prospects.

There are certain risks and critiques of storytelling as a pedagogical method. Stories are not objective, because they have been lived by the storyteller. Science must be based on facts, while stories add a bit of fiction to it. Certainly, stories cannot be the sole method in teaching chemistry. The complexity and indirectness of stories mean that the storyteller must be exceedingly well-prepared, even beyond the scope of the material, and able to rapidly adjust to the demands of the listeners and ensure they do not lose either the story or the content it is communicating.

It should be noted that the future in the application of the storytelling method in the educational process is associated with the use of its digital version, which is a composite teaching tool that combines visual, figurative, sound, and verbal components in the format of a video clip, presentation, or a standardized web page with multimedia content.

\section{References}

Aldersey-Williams, H. (2011). Periodic tales: the curious lives of the elements. Penguin.

Asimov, I. (1962). The chemicals of life. Signet.

Asimov, I. (1974). Inside the atom. Abelard-Schuman.

Ball, P. (1994). Designing the molecular world: chemistry at the frontier. Princeton University Press.

Bolte, C., Streller, S., \& Hofstein, A. (2013). How to motivate students and raise their interest in chemistry education? In Teaching chemistry - A study book: A practical guide and textbook for student teachers, teacher trainees and teachers (pp. 67-95). Sense publishers. https://doi.org/10.1007/978-94-6209-140-5_3

Buchachenko, A. L. (2020). The beauty and fascination of science. Springer Nature.

Chelnokova, E. A., Kaznacheeva, S. N., Kalinkina, K. V., \& Grigoryan, N. M. (2017). Storytelling kak technologia effektivnych kommunikacij [Storytelling as a technology of effective communications]. Prospects of Science and Education, 5, 7-12.

Collins, S. N. (2021). The importance of storytelling in chemical education. Nature Chemistry, 13(1), 1-2. https://doi.org/10.1038/s41557-020-00617-7

Dias, D., Ferraz-Caetano, J., \& Paiva, J. (2021). "Ethics against chemistry": Solving a crime using chemistry concepts and storytelling in a history of science-based interactive game for middle school students. Journal of Chemical Education, 98(5), 1681-1690. https://doi.org/10.1021/acs.jchemed.0c01469 
Ermolaeva, Zh. E., \& Lapukhova, O. V. (2016). Storytelling kak pedagogicheskaya technika konstruirovanija uchebnych zadach $\mathrm{v}$ vuze [Storytelling as a pedagogical technique for designing educational tasks at a university]. Scientific and Methodological Electronic Journal "Concept". http://e-koncept.ru/2016/16132.htm

Ermolaeva, Zh. E., Lapukhova, O. V., Gerasimova, I. N., \& Smirnova, V. A. (2017). Storytelling kak pedagogicheskaja technika peredachi javnogo i nejavnogo znanija v vuze [Storytelling as a pedagogical technique for transferring explicit and implicit knowledge in a university]. Educational Technologies, 1, 73-90.

Farmer, S. (2017). Strange chemistry: The stories your chemistry teacher wouldn't tell you. Wiley.

Folino, D. A. (2001). Stories and anecdotes in the chemistry classroom. Journal of Chemical Education, 78(12), 1615. https://doi.org/10.1021/ed078p1615

Gallagher, K. M. (2011). In search of a theoretical basis for storytelling in education research: Story as method. International Journal of Research \& Method in Education, 34(1), 49-61. https://eric.ed.gov/?id=EJ922621

Green pigment spins chip promise. http://news.bbc.co.uk/2/hi/technology/4776479.stm

Green, M. C. (2004). Storytelling in teaching. APS Observer, 17. https://www.psychologicalscience. org/observer/storytelling-in-teaching

Hargittai, I. (2002). Candid science I: Conversations with famous chemists. Imperial College Press.

Hargittai, I. (2003). Candid science III: More conversations with famous chemists. Imperial College Press.

Hoffman, R. (1997). The same and not the same. Columbia University Press.

Homann, M. (2017). How science teachers can use storytelling. Word nerd and creative digital octopus. Formally Content Marketing Manager. https://www.labster.com/how-scienceteachers-can-use-storytelling

Ihde, A. J. (1971). Let's teach history of chemistry to chemists! Journal of Chemical Education, $48,686-687$.

Jaffe, B. (2012). Crucibles: The story of chemistry from ancient alchemy to nuclear fission. Dover Publication (4th Edition).

Kean, S. (2011). The disappearing spoon: And other true tales of madness, love, and the history of the world from the Periodic table of the elements. Paperback Back Bay Books (Reprint edition).

Khaletsky, V. A., Khaletskaya, K. V., \& Vasilevskaya, E. I. (2012). Ximija i zhivopis': zagadka sinego cveta [Chemistry and painting: The riddle of blue color]. Ximiya: prablemy vykladannya, 3, 59-64.

Khaletsky, V. A., Khaletskaya, K. V. \& Vasilevskaya, E. I. (2012). Ximija i zhivopis': kobaltovue pigment [Chemistry and painting: Cobalt pigments]. Ximiya: prablemy vykladannya, 4, 5963.

Kortam, N., Hugerat, M., \& Mamlok-Naaman, R. (2020). The story behind the discovery: Integrating short historical stories in science teaching. Chemistry Teacher International. https://doi.org/10.1515/cti-2019-0016

Kuramshin, A. (2017). Zhizn' zamechatel'nykh veshchestv. [The life of remarkable substances]. Moscow: AST.

Landrum, R. E., Brakke, K., \& McCarthy, M. A. (2019). The pedagogical power of storytelling. Scholarship of Teaching and Learning in Psychology, 5(3), 247253. https://doi.org/10.1037/st10000152

Le Couteur, P., \& Burreson, J. (2003). Napoleon's buttons: How 17 molecules changed history. Teacher.

Locatelli, S. W. (2021). Reflecting upon fake news in today's post-truth era. Problems of Education in the 21st Century, 79(4), 513-515. https://doi.org/10.33225/pec/21.79.513 
Lopesa, L. G. F., Sadlerc, P. J., Bernardes-Génissond, V., Mouraf, J. J. G., Chauvind, R., Bernhardtg, P. V., \& Sousaa, E. H. S. (2020). The fundamental importence of basic science: Examples of high-impact discoveries from an international chemistry network. Quimica Nova, 43(8), 1176-1189.

Luna, R. E. (2013). The art of scientific storytelling: Transform your research manuscript with a step-by-step formula. Amado International.

Mahanti, S. (2014). Some pioneers of modern chemistry. Vigyan Prasar (New Delhi, India).

Milanovic, V. D., \& Trivic, D. D. (2020). Arguments of 14-year-olds in the context of history of the development of organic chemistry. Science \& Education, 29(1), 4374. https://doi.org/10.1007/s11191-019-00092-8

Morais, C. (2015). Storytelling with chemistry and related hands-on activities: Informal learning experiences to prevent "chemophobia" and promote young children's scientific literacy. Journal of Chemical Education, 92(1), 58-65. https://doi.org/10.1021/ed5002416

Pabuccu, A., \& Erduran, S. (2016). Investigating students' engagement in epistemic and narrative practices of chemistry in the context of a story on gas behavior. Chemistry Education. Research and Practice, 17(3), 523-531. https://doi.org/10.1039/C6RP00011H

Peleg, R., Yayon, M., Katchevich, D., Mamlok-Naaman, R., Fortus, D., Eilks, I., \& Hofstein, A. (2017). Teachers' views on implementing story telling as a way to motivate inquiry learning in high-school chemistry teaching. Chemistry Education. Research and Practice, 18(2), 304-309. https://doi.org/10.1039/C6RP00215C

Rayner-Canham, M., \& Rayner-Canham, G. (1998). Women in chemistry. American Chemical Society and the Chemical Heritage.

Stocker, J. H. (1999). Chemistry and science fiction. American Chemical Society Publication.

Storr, W. (2019). The science of storytelling. William Collins.

Thénard, J. (1803-1804). Considérations générales sur les couleurs, suivies d'un procédé pour préparer une couleur bleue aussi belle que l'outremer [General considerations on colors, followed by a process for preparing a blue color as beautiful as ultramarine]. Journal des Mines, 86, 128-136.

Winston, J., \& Mission, S. (2017). Teaching chemistry as a story: Using narrative structure as a framework for science education. Electronic Journal of Science Education, 23(3), 58- 72. http://ejse.southwestern.edu

Zakharov, L. N. (1991). Technika bezopasnosti v chimicheskich laboratorijach [Safety technology in chemical laboratories]. Chemistry.

Received 28 October 2021; Accepted 21 December 2021 
Cite as: Vasilevskaya, E., \& Boboriko, N. (2021). The storytelling: An effective tool in the teaching of high-level chemistry. Gamtamokslinis ugdymas / Natural Science Education, 18(2), 93-104. https://doi.org/10.48127/gu-nse/21.18.93

\section{Elena Vasilevskaya}

$\mathrm{PhD}$, Associate Professor, Faculty of Chemistry, Belarusian State University, 14 Leningradskaya Street, Minsk, Republic of Belarus.

E-mail: Vasileli@bsu.by

Website: https://scholar.google.com/citations?user=XqBA1QkAAAAJ\&hl=th

ORCID: https://orcid.org/0000-0003-4358-0124

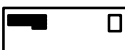

Natalia Boboriko

$\mathrm{PhD}$, Associate Professor, Faculty of Chemistry, Belarusian State University, 14 Leningradskaya Street, Minsk, Republic of Belarus.

E-mail: boboriko@bsu.by

Website: https://www.researchgate.net/profile/Natalia_Boboriko

ORCID: https://orcid.org/0000-0002-4794-7424 